\title{
Diffusion and Gas Conversion Analysis of Solid Oxide Fuel Cells at Loads via AC Impedance
}

\author{
Robert U. Payne, ${ }^{1}$ Ying Zhu, ${ }^{1}$ Wenhua H. Zhu, ${ }^{1}$ Mark S. Timper, ${ }^{2}$ S. Elangovan, ${ }^{2}$ \\ and Bruce J. Tatarchuk ${ }^{1}$ \\ ${ }^{1}$ Center for Microfibrous Materials, Department of Chemical Engineering, 212 Ross Hall, Auburn University, AL 36849, USA \\ ${ }^{2}$ Ceramatec, Inc., 2425 South 900 West, Salt Lake City, UT 84119, USA
}

Correspondence should be addressed to Bruce J. Tatarchuk, brucet@eng.auburn.edu

Received 16 June 2011; Accepted 25 July 2011

Academic Editor: Boniface Kokoh

Copyright (C) 2011 Robert U. Payne et al. This is an open access article distributed under the Creative Commons Attribution License, which permits unrestricted use, distribution, and reproduction in any medium, provided the original work is properly cited.

\begin{abstract}
Impedance measurements were conducted under practical load conditions in solid oxide fuel cells of differing sizes. For a $2 \mathrm{~cm}^{2}$ button cell, impedance spectra data were separately measured for the anode, cathode, and total cell. Improved equivalent circuit models are proposed and applied to simulate each of measured impedance data. Circuit elements related to the chemical and physical processes have been added to the total-cell model to account for an extra relaxation process in the spectra not measured at either electrode. The processes to which elements are attributed have been deduced by varying cell temperature, load current, and hydrogen concentration. Spectra data were also obtained for a planar stack of five $61 \mathrm{~cm}^{2}$ cells and the individual cells therein, which were fitted to a simplified equivalent circuit model of the total button cell. Similar to the button cell, the planar cells and stack exhibit a pronounced low-frequency relaxation process, which has been attributed to concentration losses, that is, the combined effects of diffusion and gas conversion. The simplified total-cell model approximates well the dynamic behavior of the SOFC cells and the whole stack.
\end{abstract}

\section{Introduction}

Solid oxide fuel cells (SOFCs) have become a more attractive solution for power generation due to their higher energy efficiency, fuel flexibility, high-quality waste heat, tolerance to carbon monoxide, and lower/zero emissions [1-3]. Effort has been made for fuel cell R\&D and commercialization over the last several decades, with increasing concerns of fossil fuel rapid consumption and global warming from $\mathrm{CO}_{2}$ exhaust. For consideration of successful fuel cell commercialization, there are two major challenges, high cost and low reliability [4]. It is significantly important to have deep understanding of the electrode structures, catalytic mechanisms, reaction limitations, and failure mode diagnostics [5] in order to approach a technical breakthrough. AC impedance spectroscopy has been widely used for fuel cell characterization, reaction mechanism, and performance degradation analysis among those fuel cell diagnostic tools [6-8].

The dynamic load response of the device must be well understood in order to implement fuel cells into a power system. Impedance spectroscopy is a measurement technique capable of assessing the dynamic response characteristics of an electrochemical system [9] and is performed by superimposing an AC signal on the DC output of an electrochemical cell and measuring the impedance over a spectrum of frequencies. These data are often fitted with an equivalent circuit model, which is a circuit of electrical elements producing a similar load response to the device under investigation [10]. These models are useful for designing the power conditioning system, through which the electrochemical device supplies power to a load.

Equivalent circuits are also beneficial for stack diagnostics, because the different circuit elements theoretically represent different physical relaxation processes occurring in the electrochemical cell(s) $[11,12]$; hence, fit data can be used to distinguish which processes are limiting cell behavior and to what extent. AC impedance is further useful for assessing system design and component fabrication, monitoring system aging and state of health, and performing quality control. 
Using electrochemical impedance spectroscopy, An et al. [13] measured the half-cell performance of the SOFCs and performed the durability analysis of the composite cathode after $1000 \mathrm{~h}$ of aging. Oestergard and Mogensen [14] conducted the kinetics study of the oxygen reduction reaction via AC impedance spectroscopy. Kato et al. [15] carried out impedance measurements under practical power generation conditions in a disk-type SOFC. Liu et al. [16] fabricated a micro-SOFC stack, and it was operated under singlechamber conditions. Impedance spectra data of each cell were measured and analyzed under open-circuit conditions. Because of equipment limitations and the desire to maintain constant temperature and reactant concentration, most measurements of AC impedance data have been performed near open circuit voltage (OCV). These investigations offer little insight into the behavior of a polarized cell. The few studies that have tested a cell under load have overcome the power limitations of their equipment by testing electrodes much smaller than commercial ones. An additional benefit of small cell studies is that cell conditions (reactant concentration, temperature, current, potential, etc.) are less distributed than in larger cells. This hinders the ability to scale up a small cell model to predict the behavior of a larger cell, but the small cell results are a beneficial reference for the larger SOFC work. Lang et al. [17] applied electrochemical impedance spectroscopy at different operating gases and different electrical current loads to characterize solid oxide fuel cell short stacks for mobile applications. The nature of losses including ohmic and polarization resistances of the electrodes were examined and determined by fitting the impedance spectra to an equivalent circuit.

When operating in a stack, individual cells are expected to behave differently due to manufacturing inconsistencies and flow, current, and temperature distribution. Testing cells under the most realistic conditions possible is desirable for sound understanding of working systems. This paper presents results and analysis of impedance spectra from solid oxide fuel cells at electrical current loads, the results of which are augmented by button cell studies. The improved totalcell models are proposed for the SOFC cells and fitted to impedance spectra data obtained from the fuel cell tests. Further analysis and discussion on the diffusion and gas conversion processes are conducted for the total SOFC cells and larger planar cells in the stack.

\section{Experimental}

Two different sizes of SOFC cells (button cells and larger planar cells, Ceramatec, Inc.) were operated and tested in the experimental work. Both consisted of a zirconia-based electrolyte (ca. $170 \mu \mathrm{m}$ thick), a nickel-based anode, and a manganite-based cathode. The cells were fed at $c a .15$ psig with air on the cathode side and mixtures of hydrogen and nitrogen bubbled through water on the anode side. Cell temperature was maintained with furnaces controlled by a LabVIEW (National Instruments) program. Furnaces were cooled down to $500^{\circ} \mathrm{C}$ during long intervals between tests (e.g., overnight) to minimize cell aging.
The button cells consisted of an $8 \mathrm{~cm}^{2}$ disc of electrolyte onto either side of which $2 \mathrm{~cm}^{2}$ electrodes were brushed. A small reference electrode of the same material as the corresponding electrode was brushed on both sides of the electrolyte near the electrode. The SOFC cells were tested using a Solartron Analytical 1255 A frequency response analyzer in conjunction with a Schlumberger SI-1286 potentiostat/galvanostat. The tests were controlled and data were recorded through a LabVIEW program. Separate spectra were acquired galvanostatically for the anode, cathode, and total cell at a given current. In each case, the system was perturbed with a sinusoidal wave of $5 \mathrm{mV}$ amplitude over a spectrum of $1.0 \mathrm{MHz}$ to $10 \mathrm{mHz}$. The independent variables studied were cell current, cell temperature, and anode feed composition. Gas mixtures were altered using rotameters upstream from the water bubbler maintaining a total flow of 39 SCCM. Outlet gas compositions were measured with a molecular sieve column in an Agilent $3000 \mathrm{~A}$ gas chromatograph and analyzed with Agilent's Cerity Network Data System software. Inlet compositions were assumed to be equal to those of the outlet at open circuit.

The planar stack consisted of five cells, each with an electrode area of $61 \mathrm{~cm}^{2}$. The stack was fed with 1.5 SLPM air and 2.2 SLPM differing anode mixtures of hydrogen and nitrogen bubbled through water. Anode inlet compositions were measured using the same Agilent system as before. Stack temperature was regulated to be $800^{\circ} \mathrm{C}$ using a similar furnace and LabVIEW program as in the button cell tests. Impedance spectra were measured with an FC350 potentiostat (Gamry Instruments) in conjunction with a TDIDynaload RBL488 programmable load. Data were acquired at different stack currents for the cells on both ends of the stack (Cells 1 and 5) and the middle cell (Cell 3), as well as for the entire stack. The sinusoidal waves were generated galvanostatically with currents producing a maximum potential amplitude of $5 \mathrm{mV}$ (35-140 mA RMS depending on the operating DC current). All spectra collected from either cell size were fitted to equivalent circuits with Gamry's Echem Analyst software using the Levenberg-Marquardt algorithm.

Impedance for the button cell was measured for the total cell as well as separately for anode and cathode with respect to a reference electrode at each test condition. The equivalent circuit models from button cell results are properly combined, simplified, and then applied to those of the large cells and stack. The fitted circuit elements are assigned to physical phenomena to determine which and to what extent physical processes limit stack power output.

\section{Results and Discussion}

Total-cell impedance data were analyzed in terms of equivalent circuits based on separately measured button cell anode and cathode spectra. The association of different circuit elements with physical processes occurring within the cell was verified by varying cell conditions. Total button cell model fits were compared to those of the individual electrodes, to identify differences and accordingly adjust the total-cell equivalent circuit configuration. The button cell 
analyses were then conducted for reaction mechanisms and related physical processes.

3.1. Equivalent Circuit Models. SOFC cell models are based on button cell spectra, because their configuration is more conducive to impedance measurements. The picayune nature of the button cells minimized temperature and current distribution over the active surface. Furthermore, reference electrodes bonded to the button cell electrolyte allowed for the anode and cathode to be separately probed. Individual electrode spectra were analyzed in terms of equivalent circuit models, which were then combined into a total-cell circuit. The full button cell model was modified based on experimental data and simplified for large cell analysis.

3.1.1. Half-Cell Measurements. Impedance spectra were measured separately for anode and cathode at different temperatures, DC load currents, and anode gas compositions. Anode and cathode data were well fitted to a three- and a two-RC equivalent circuit model, respectively (Figures 1 and 2). The cathode fits were obtained using a constant phase element (CPE) in place of the $C_{d}$. In-depth analysis of the fitted circuit elements is ill-advised, because studies $[18,19]$ have indicated that bonding a reference electrode to the same face of a solid electrolyte as the working electrode likely produces erroneous data. Researchers also showed that the high- and low-frequency intercepts may be shifted and that an extraneous arc may exist at the frequency limits. As such, specific values of the half-cell fits are still capable of indicating general trends in the simulation. This data simulation and analysis are helpful for providing insight into the findings of related anode/cathode reactions and transport processes in the whole SOFC cell. Furthermore, only $R_{\mathrm{ct}}$ and $C_{d}$ in the circuits are assumed to be ascribed to real phenomenon (anode and cathode activation), whether the low-frequency elements in the models are caused by cell geometry or adsorbed intermediates. Overall, the total-cell spectra data is reliable without the effect of shape, size, and location of the reference electrodes.

3.1.2. Total-Cell Equivalent Circuit Model. The frequencydependent impedance was measured between the anode and cathode under each of the same conditions as for the halfcell tests. A full-cell equivalent circuit is typically that of the anode added in series with the cathode, wherein the ohmic contributions are combined into a single resistor. Such an arrangement is theoretically well fitted to total-cell data assuming its spectrum was obtained at the same conditions as the individual electrode spectra; however, Figure 3 depicts a large arc dominating the low-frequency data from the full-cell that is not present in the summed half cells. The extraneous arc is not unique to the button cells and exists in the larger cell spectra (Figure 4) as well, albeit with an abscissa shifted to a higher frequency.

To aid the identification of the process responsible for the low-frequency impedance arc, the button cell data have been fitted to two different equivalent circuits. Both models consist of the cathode and anode equivalent circuits used for the single-electrode fits in series and fixed to the previously

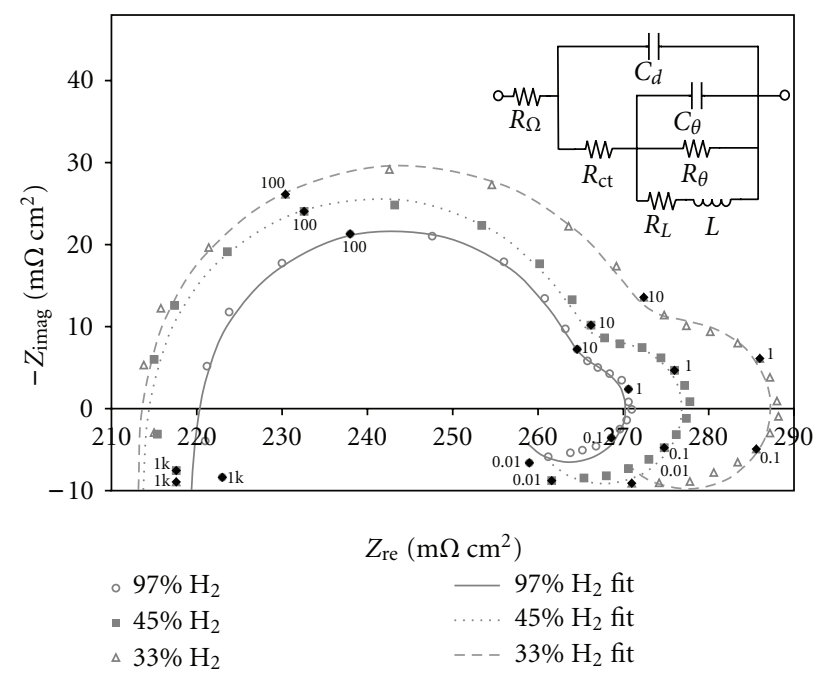

FIGURE 1: Nyquist plot for a button cell anode operating at $800^{\circ} \mathrm{C}$ and $175 \mathrm{~mA} \mathrm{~cm}^{-2}$ and fed with $3 \% \mathrm{H}_{2} \mathrm{O}$ and $\mathrm{H}_{2}$ diluted with varying amounts of $\mathrm{N}_{2}$. Data fits were obtained with the anode equivalent circuit model in the right-hand corner of the figure.

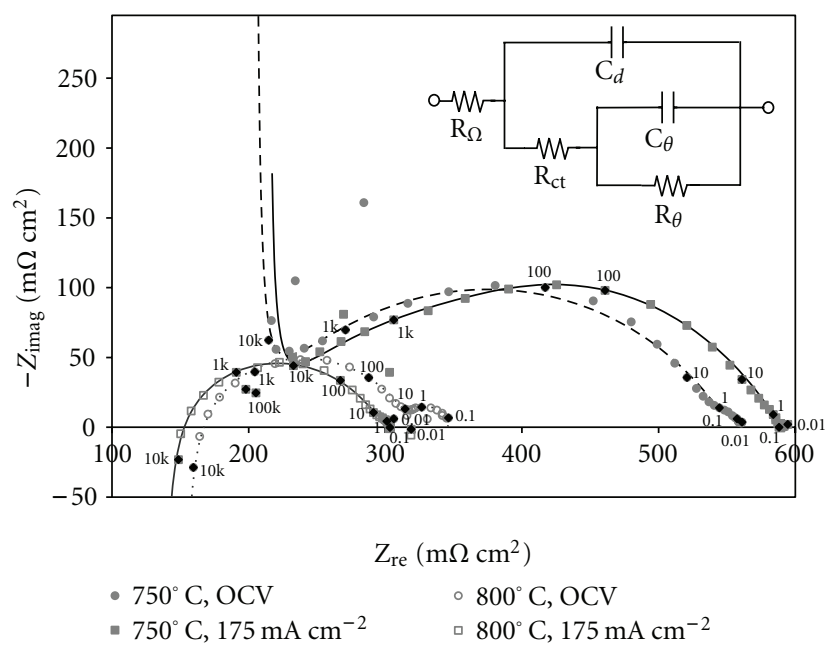

FIgure 2: Nyquist plot for a button cell cathode fed with air and operating at varying temperature and load current. The data fits were obtained with the cathode equivalent circuit model in the right-hand corner of the figure. Note that a CPE is used to fit the data in place of the $C_{d}$.

obtained values. A single $R_{\Omega}$ is in series with both circuits along with an $L$ for lead inductance. To fit the low-frequency loop, a parallel resistor and capacitor were added in series to one of the circuits (Figure 5(a)), while a finite diffusion element (FDE) was added to the other (Figure 5(b)). The impedance of the FDE [20] is approximately described as

$$
Z_{\mathrm{FDE}}=\left(\frac{1}{Y_{0} \sqrt{j \omega}}\right) \tanh (B \sqrt{j \omega})
$$




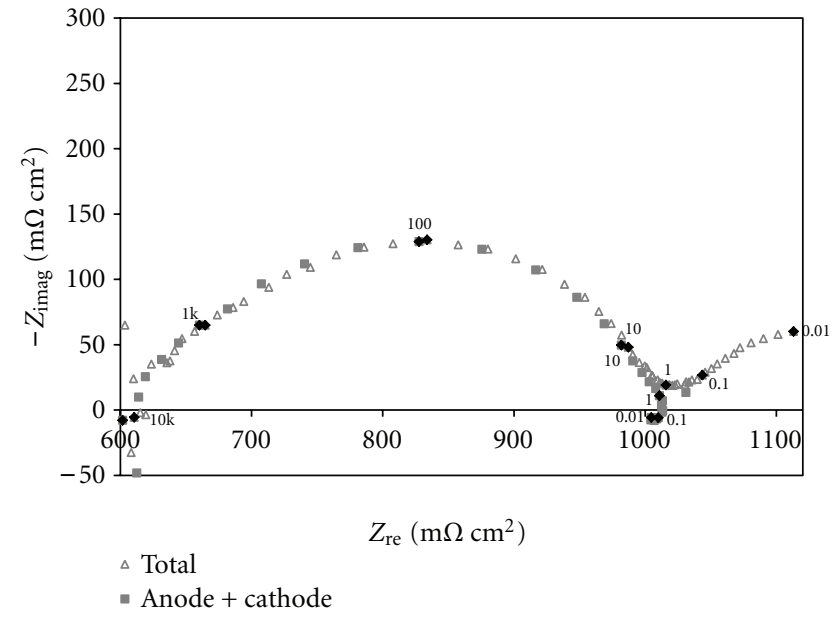

FIgURE 3: Nyquist plot of the total cell compared with the sum of the individual anode and cathode spectra for a button cell operating at $750{ }^{\circ} \mathrm{C}$ and $175 \mathrm{~mA} \mathrm{~cm}^{-2}$ and fed with $3 \% \mathrm{H}_{2} \mathrm{O}$ and balance $\mathrm{H}_{2}$. A large low-frequency arc is unique to the measured total-cell impedance.

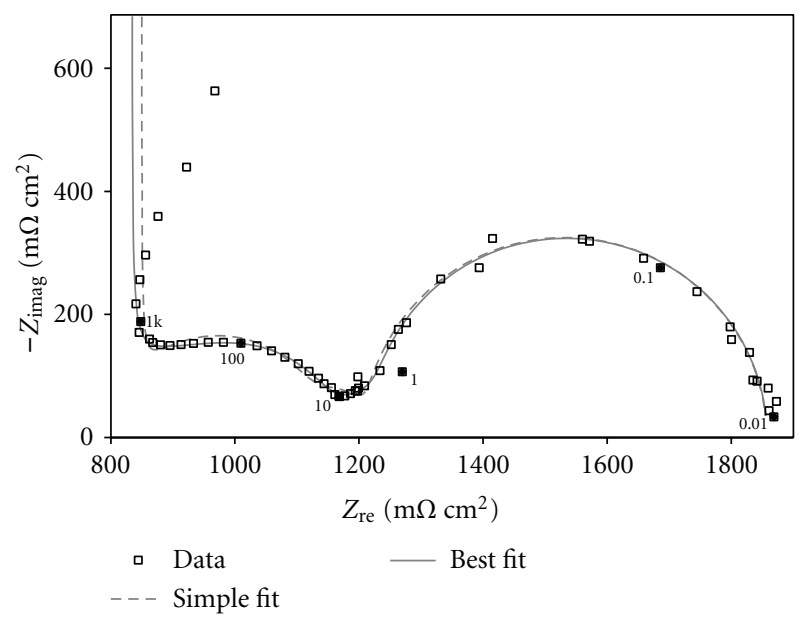

FIgURE 4: Nyquist plot of a planar fuel cell operating at $800^{\circ} \mathrm{C}$ and $52 \mathrm{~mA} \mathrm{~cm}^{-2}$ and fed with $3 \% \mathrm{H}_{2} \mathrm{O}, 45 \% \mathrm{H}_{2}$, and balance $\mathrm{N}_{2}$. The cell has been fitted to two different equivalent circuits: one with three RC circuits (simple fit) and the other with four (best fit).

where

$$
\begin{gathered}
Y_{0}=\frac{(n F)^{2} A}{R_{\mathrm{ig}} T}\left(\sum \frac{1}{c_{i} \sqrt{D_{i}}}\right)^{-1}, \\
B=\frac{\delta}{\sqrt{D_{i}}} .
\end{gathered}
$$

In theory, the location of the FDE in the equivalent circuit is related to the diffusing species: ionic diffusion is in series with the $R_{\Omega}$, while $\mathrm{H}_{2}$ or $\mathrm{O}_{2}$ diffusion would be in series with the Faradaic impedance branch of the respective electrode. Table 1(a) compares fitted values for the FDE in series with $R_{\Omega}$ (as in Figure 5(b)) against those in series with $R_{\mathrm{ct}}^{a}$, which are markedly similar. Fortunately, because of the insignificant change in fitted values with changing circuit topography, information can be inferred from the fits without knowing the low-frequency limiting process a priori. In Section 3.3, the low-frequency impedance arc is further discussed in details.

Regardless of whether the extra semicircle is modeled with an FDE or a parallel RC, the total-cell circuits (Figures 5(a) and 5(b)) must be simplified in order to fit the larger cells and stacks. Fitting a circuit with so many elements of unknown value is rife with error, which is not an issue for the button cells, because the anode and cathode elements were set equal to the values obtained from the half-cell fits. In simplifying the circuit, the minimum number of elements producing an $\mathrm{RC}$ circuit required to fit the data would be three: an FDE (or parallel low-frequency RC) and a parallel RC for the anode as well as the cathode. Figure 4 shows that the three-RC circuit model is too simple needing a fourth RC circuit to fit the data more exactly. The additional elements are ascribed to the anode (likely adsorption), because its effect on half-cell impedance is the most pronounced of the omitted elements (Figure 1); hence, it is in series with the Faradaic impedance branch of the anode in the large cell equivalent circuit model depicted in Figure 6. The values of the fitted circuit elements are listed in Table 2. In essence, each electrode model has been simplified for the total-cell fit by removing the pair of elements least influencing the shape of their respective half-cell curves, which is further supported by the dubious low-frequency behavior of the reference electrode configuration. Now that the total-cell equivalent circuit model has been simplified, the validity of the model may be tested by examining the variation of the fitted values with respect to changing cell conditions.

3.2. High-Frequency Fits. Half-cell and total-cell impedance spectra are dominated by kinetics in the range of $10 \mathrm{kHz}-$ $1 \mathrm{~Hz}$ for the button cells, which are henceforth referred to as the high-frequency range. The button cell spectra demonstrate the expected trends in the variance of high-frequency impedance. Figure 1 shows the $R_{\mathrm{ct}}^{a}$ increasing as the anode feed gas is diluted with inert gas $\left(\mathrm{N}_{2}\right)$. Cooling a cell from $800^{\circ} \mathrm{C}$ to $750^{\circ} \mathrm{C}$ also increases cell impedance as evident in Figure 2, which is partially why SOFCs must be run at such high temperatures. The shape of loop changes to the normal Nyquist plot with increase of temperature. Barbucci et al. [22] conducted the analysis of oxygen reduction on porous composite electrodes for better understanding of the mechanism of the SOFC cathode behavior. It gives similar Nyquist plots at high-frequency loop for the half cell with composite cathode at different temperatures.

As for the variance of $R_{\mathrm{ct}}$ with respect to current, the energy required to surmount the activation barrier is smaller at a larger overpotential; hence, $R_{\mathrm{ct}}$ is expected to decrease as the overpotential (polarization) is increased. Note that 97\% hydrogen anode feeds are used to verify changes in cell polarization (Figure 7), because when inert gases are present equivalent inlet compositions are not comparable for varying cell current due to reactant consumption. While button cell electrode configuration may cause errors in the half-cell 


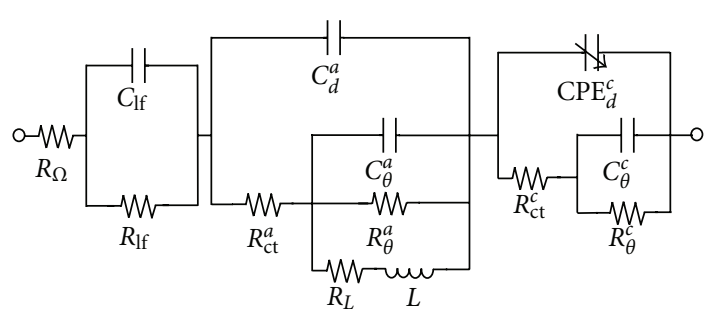

(a)

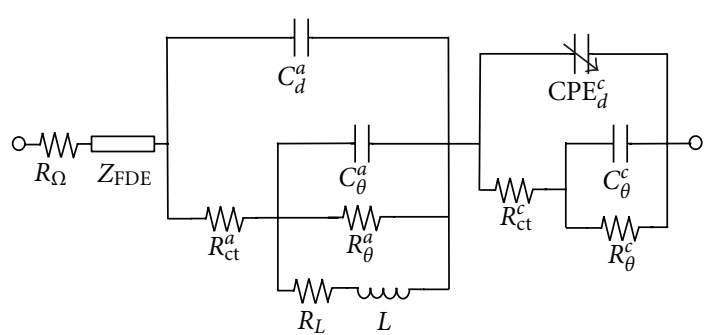

(b)

FIGURE 5: Equivalent circuit model for a total button cell consisting of the button cell anode and cathode equivalent circuits in series with (a) a parallel RC (simple fit, $R_{\mathrm{lf}}$ and $C_{\mathrm{lf}}$ ) or (b) an FDE element (best fit).

TABLE 1: Values for a parallel RC as shown in Figure 5(a) are fitted to the low-frequency impedance loops of button cells.

(a) Varying hydrogen feed concentration at two temperatures

\begin{tabular}{|c|c|c|c|c|c|c|c|}
\hline Physical elements & $R_{\mathrm{lf}}$ & $C_{\mathrm{lf}}$ & $Y_{0}$ & $B$ & $Y_{0}^{*}$ & $B^{*}$ & Note \\
\hline$x_{H}\left(T=750^{\circ} \mathrm{C}\right)$ & $\left(\mathrm{m} \Omega \mathrm{cm}^{2}\right)$ & $\left(\mathrm{F} \mathrm{cm}^{-2}\right)$ & $\left(\mathrm{S} \mathrm{cm}^{-2} \mathrm{~s}^{1 / 2}\right)$ & $\left(s^{1 / 2}\right)$ & $\left(\mathrm{S} \mathrm{cm}^{-2} \mathrm{~s}^{1 / 2}\right)$ & $\left(s^{1 / 2}\right)$ & \multirow{4}{*}{$i=175 \mathrm{~mA} \mathrm{~cm}^{-2}$} \\
\hline $47.3 \%$ & 138.5 & 40.60 & 25.66 & 4.493 & 25.71 & 4.493 & \\
\hline $63.7 \%$ & 137.4 & 41.40 & 26.13 & 4.412 & 26.42 & 4.435 & \\
\hline $97.0 \%$ & 120.1 & 51.85 & 31.25 & 4.700 & 31.43 & 4.713 & \\
\hline \multicolumn{8}{|l|}{$x_{H}\left(T=800^{\circ} \mathrm{C}\right)$} \\
\hline $33.1 \%$ & 172.3 & 58.45 & 26.76 & 5.441 & 27.53 & 5.532 & \multirow{3}{*}{$i=175 \mathrm{~mA} \mathrm{~cm}^{-2}$} \\
\hline $45.5 \%$ & 146.9 & 78.55 & 35.56 & 6.090 & 33.32 & 5.831 & \\
\hline $97.0 \%$ & 123.6 & 88.35 & 37.98 & 5.643 & 40.64 & 5.079 & \\
\hline
\end{tabular}

${ }^{*}$ The finite diffusion element (FDE), fitted in series with the Faradaic impedance as shown in Figure 5(b), is also listed in this Table 1(a), showing little difference between the parallel RC and the series fits.

(b) Varied load current density at two hydrogen feed concentrations

\begin{tabular}{|c|c|c|c|c|c|}
\hline Physical elements & $R_{\mathrm{lf}}$ & $C_{\mathrm{lf}}$ & $Y_{0}$ & $B$ & Note \\
\hline$i\left(\mathrm{~mA} \mathrm{~cm}^{-2}, x_{\mathrm{H}}=33.1 \%\right)$ & $\left(\mathrm{m} \Omega \mathrm{cm}^{2}\right)$ & $\left(\mathrm{F} \mathrm{cm}^{-2}\right)$ & $\left(\mathrm{S} \mathrm{cm}^{-2} \mathrm{~s}^{1 / 2}\right)$ & $\left(s^{1 / 2}\right)$ & \multirow{4}{*}{$\begin{array}{l}T=800^{\circ} \mathrm{C}, \\
x_{w}=3.0 \%, \\
\text { Balance } \mathrm{N}_{2}\end{array}$} \\
\hline 0.000 & 638.8 & 16.99 & 7.215 & 6.078 & \\
\hline 175.0 & 172.3 & 58.45 & 26.76 & 5.441 & \\
\hline 300.0 & 126.4 & 75.65 & 35.28 & 5.313 & \\
\hline \multicolumn{6}{|l|}{$i\left(\mathrm{mAcm}^{-2}, x_{\mathrm{H}}=45.5 \%\right)$} \\
\hline 0.000 & 620.4 & 16.42 & 7.310 & 5.849 & \multirow{3}{*}{$\begin{array}{l}T=800^{\circ} \mathrm{C} \\
x_{w}=3.0 \% \\
\text { Balance } \mathrm{N}_{2}\end{array}$} \\
\hline 175.0 & 146.9 & 78.55 & 35.56 & 6.090 & \\
\hline 300.0 & 100.0 & 103.4 & 45.15 & 5.595 & \\
\hline
\end{tabular}

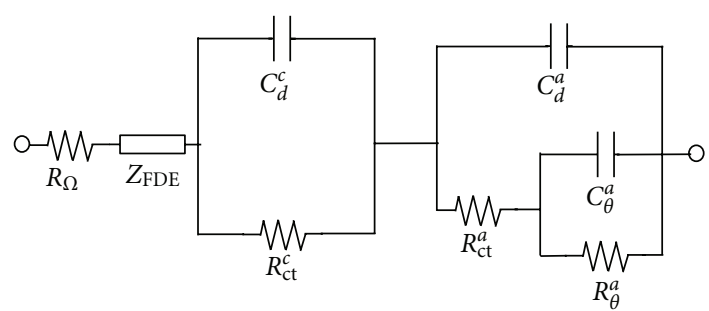

FIGURE 6: Large cell equivalent circuit model. The circuit has four $\mathrm{RC}$ circuits associated with the parallel RCs $\left(R_{\mathrm{ct}}^{a} C_{d}^{a}, R_{\mathrm{ct}}^{c} C_{d}^{c}\right.$, and $\left.R_{\theta}^{a} C_{\theta}^{a}\right)$ and the finite diffusion element $\left(Z_{\mathrm{FDE}}\right)$.

data, the charge-transfer behavior trended as expected and is applied to test the veracity of the large cell fits.
Impedance data collected for the SOFC total cell are graphed in a Nyquist plot as shown in Figure 4, and the experimental data have the same upward trend at highfrequency region as impedance data plotted by Lang et al. [17] for a one-cell short stack. Data are well fitted to the total-cell model, but the mechanistic trends are not always correct in the charge-transfer dominated part of the SOFC cell impedance spectra. One reason is that the impedance spectra for the large cells are dominated by the low-frequency curve (Figure 4). Another source of fit error is in the relaxation times of the anode and cathode being similar enough to cause their respective curves to overlap. Because the electrodes are indistinguishable, the variation in $R_{\mathrm{ct}}^{a}$ and $R_{\mathrm{ct}}^{c}$ does not necessarily match the theoretical trends confirmed in the half-cell measurements. The $R_{\mathrm{ct}}$ fits vary with changing $\mathrm{H}_{2}$ concentration and load current as shown 
TABLe 2: Fitted equivalent circuit elements using the circuit model as shown in Figure 6, varying anode fuel feeds for three individual cells in a five-cell stack, and operating at $800^{\circ} \mathrm{C}, 52.46 \mathrm{~mA} \mathrm{~cm}^{-2}$. Feeds were $38.5 \sim 97.0 \% \mathrm{H}_{2}, 3.0 \% \mathrm{H}_{2} \mathrm{O}$, and balance $\mathrm{N}_{2}$.

\begin{tabular}{|c|c|c|c|c|c|c|c|c|c|}
\hline \multirow{2}{*}{ Physical elements } & \multicolumn{3}{|c|}{$x_{H}($ Cell 1) } & \multicolumn{3}{|c|}{$x_{H}($ Cell 3) } & \multicolumn{3}{|c|}{$x_{H}($ Cell 5) } \\
\hline & $38.5 \%$ & $64.6 \%$ & $97.0 \%$ & $38.5 \%$ & $64.6 \%$ & $97.0 \%$ & $38.5 \%$ & $64.6 \%$ & $97.0 \%$ \\
\hline$R_{\Omega}\left(\mathrm{m} \Omega \mathrm{cm}^{2}\right)$ & 1316 & 1287 & 1261 & 673.4 & 661.9 & 657.6 & 805.2 & 792.4 & 792.4 \\
\hline$R_{\mathrm{ct}}^{\theta}\left(\mathrm{m} \Omega \mathrm{cm}^{2}\right)$ & 300.2 & 256.2 & 244.9 & 287.6 & 235.0 & 220.5 & 226.5 & 189.5 & 178.2 \\
\hline$C_{d}^{c}\left(\mathrm{mF} \mathrm{cm}^{-2}\right)$ & 11.50 & 15.13 & 13.56 & 11.80 & 12.16 & 14.07 & 10.28 & 10.81 & 11.42 \\
\hline$R_{\mathrm{ct}}^{a}\left(\mathrm{~m} \Omega \mathrm{cm}^{2}\right)$ & 148.8 & 174.8 & 181.4 & 115.8 & 116.6 & 141.9 & 81.62 & 87.78 & 97.23 \\
\hline$C_{d}^{a}\left(\mathrm{mF} \mathrm{cm}^{-2}\right)$ & 5.646 & 5.089 & 4.673 & 6.564 & 6.448 & 5.789 & 6.308 & 5.730 & 5.815 \\
\hline$R_{\theta}^{a}\left(\mathrm{~m} \Omega \mathrm{cm}^{2}\right)^{\dagger}$ & -118.0 & -69.17 & -39.12 & -78.32 & -74.42 & -60.45 & -68.44 & -74.60 & -61.67 \\
\hline$C_{\theta}^{a}\left(\mathrm{~F} \mathrm{~cm}^{-2}\right)^{\dagger}$ & -1.984 & -3.739 & -5.705 & -1.481 & -2.356 & -2.726 & -1.277 & -1.455 & -2.449 \\
\hline$Y_{0}\left(\mathrm{~S} \mathrm{~cm}^{-2} \mathrm{~s}^{1 / 2}\right)$ & 1.204 & 1.599 & 2.051 & 1.292 & 1.554 & 1.857 & 1.351 & 1.595 & 1.907 \\
\hline$B\left(s^{1 / 2}\right)$ & 1.445 & 1.543 & 1.668 & 1.313 & 1.394 & 1.467 & 1.337 & 1.383 & 1.457 \\
\hline$\chi^{2}\left(* 10^{-6}\right)^{\ddagger}$ & 63.7 & 44.3 & 26.9 & 171 & 97.8 & 90.4 & 182 & 126 & 76.4 \\
\hline
\end{tabular}

${ }^{\dagger}$ Negative values of $R_{\theta}$ and $C_{\theta}$ indicate that the inductive behavior of anode adsorbed intermediates is more significant than the capacitive portion. The same fits can be obtained without negative values, when the parallel $R_{\theta}-C_{\theta}$ is replaced with a series $R_{L}-L$ moved in parallel with the anode $R_{\mathrm{ct}}^{a}$ [21].

${ }^{\ddagger} \chi^{2}$ is the nonlinear least squares residual.

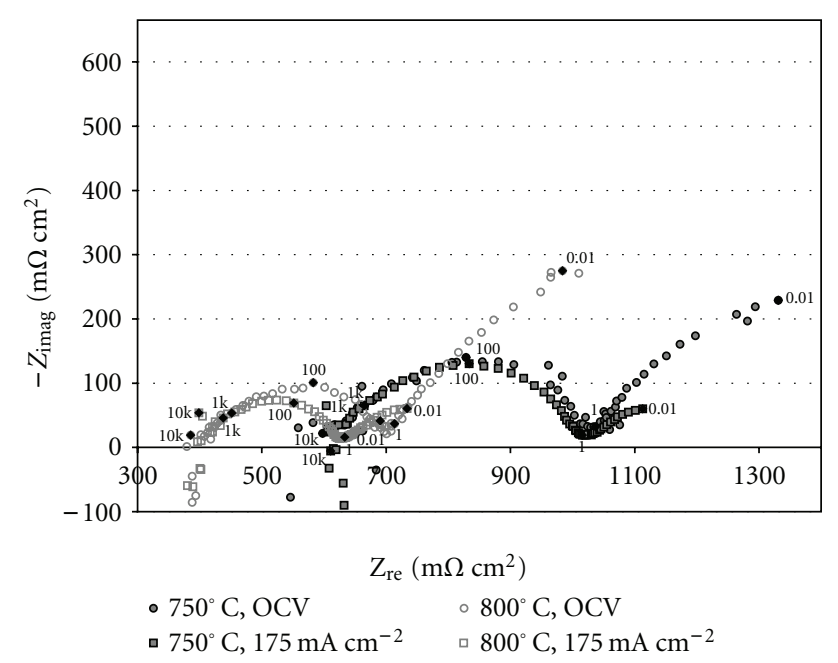

Figure 7: Nyquist plot for a total button cell fed with $97 \% \mathrm{H}_{2}$ and balance $\mathrm{H}_{2} \mathrm{O}$ and operating at varying temperature and load current.

in Table 1, respectively. The value of $R_{\mathrm{ct}}$ of the cathode ( $\mathrm{ca}$. $150 \mathrm{~m} \Omega \mathrm{cm}^{-2}$ at $800^{\circ} \mathrm{C}, 175 \mathrm{~mA} \mathrm{~cm}^{-2}$, and $97.0 \% \mathrm{H}_{2}$ in Figure 2) is approximately 3 times more higher than that of the anode $\left(\mathrm{ca} .45 \mathrm{~m} \Omega \mathrm{cm}^{-2}\right.$ at $800^{\circ} \mathrm{C}, 175 \mathrm{~mA} \mathrm{~cm}^{-2}$, and $97.0 \% \mathrm{H}_{2}$ in Figure 1). The lower valued resistance $\left(R_{\mathrm{ct}}\right.$ at the anode) decreases with increasing $x_{H}$, which is expected as shown in smaller loops in Figure 1.

If the parallel $R_{\mathrm{ct}}-C_{d}$ is instead viewed as the combined kinetic fit, then the elements vary with changing conditions as expected. In fact, a further simplified equivalent circuit (Figure 5(a)) wherein the electrode process elements are replaced by a single parallel $R_{\mathrm{ct}}-\mathrm{CPE}$ is well fitted to the large total-cell data (Figure 4). As a whole, the $R_{\mathrm{ct}}$ behavior nearly follows the trends as we expected in the simplified circuit. The high-frequency fits of the total cell are useful for determining the overall kinetic performance of the cell.
3.3. Low-Frequency Fits. The low-frequency loop of the totalcell impedance spectra is related to reactant concentration at the interface, due to either mass transfer or gas conversion. The FDE and parallel RC are used to model diffusion and gas conversion, respectively, and are fitted to the data equally well. Because the process responsible for the low-frequency arc cannot be determined from the shape of the curve, the variation of the fitted values with respect to cell conditions must be investigated to determine whether diffusion or gas conversion is the cause.

3.3.1. Mass Transfer. The impedance of mass transfer by diffusion is quantified by the fitted values of the FDE, which respond as expected to variations in temperature and reactant concentration. Heating the cell imparts more thermal energy to the system facilitating mass transport and decreasing impedance (or increasing diffusivity). Recalling the dependence of (1) and (2) on diffusivity verifies the change in the fitted $Y_{0}$ and $B$ with respect to temperature at the same cell current and reactant concentration (Table 1(a)). Note that electrolytic diffusivity is more sensitive to temperature variations $\left(D_{i} \propto e^{T}[23]\right)$ than gas phase diffusivity $\left(D_{i} \propto T^{1.75}[24]\right)$ thereby dominating the $T$ in the denominator of (2) and in gas concentration $\left(c_{i} \propto T^{-1}\right)$. The relationship between $Y_{0}$ and reactant concentration is more straightforward, increasing impedance as the feed is diluted with inert gas as explicitly shown in (1) and verified for both cell sizes in Tables 1 and 2 . The approximately constant value of $B$ with respect to changing hydrogen concentration is also as expected, as it is a variable that should not appreciably alter $D_{i}$ or $\delta$.

The variation of the FDE with respect to current is as expected for the button cells, but not so for the larger ones. Data fits in Table 1 show that button cell $Y_{0}$ increases with increasing current while $B$ remains relatively constant, which is predicted by the FDE equations. The only variables affected by a change in current are the concentration terms in the summation of (2) explaining why $B$ remains the same. The value of the summation is largely dominated by the 


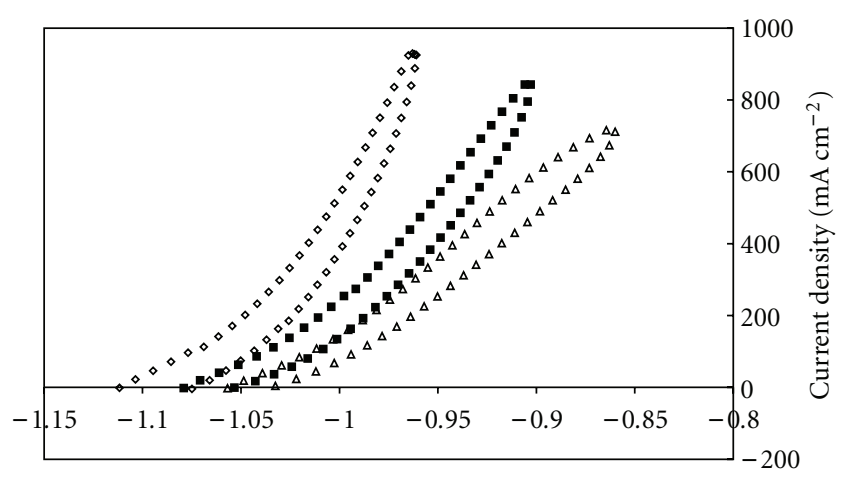

$\begin{array}{lc} & \text { Potential (V) } \\ \text { - } 97 \% \mathrm{H}_{2} & \Delta 33 \% \mathrm{H}_{2}, 64 \% \mathrm{~N}_{2} \\ \text { - } 49 \% \mathrm{H}_{2}, 48 \% \mathrm{~N}_{2} & \end{array}$

Figure 8: Potential difference between anode and cathode reference electrodes plotted as a function of load current.

reactant at lower concentration (normally water for the anode); hence, $Y_{0}$ is large at high current, where $c_{w}$ is increased from its initial amount due to the reduction of hydrogen to water. The size of the cell likely contributes to the difference between the button and larger cells, because reactant depletion at the cell outlet is more significant at higher currents and expected to have a more deleterious effect on larger cells.

To explain the paucity of a similarly large low-frequency arc in half-cell impedance spectra, the potential of the reference electrodes must be considered. If the concentrations of all reactants at the references are constant, then the potential difference between the two should be independent of the current through the cell. The curves plotted in Figure 8 indicate that concentration in fact varies at the reference surface. The absence of the low-frequency arc from anode or cathode impedance spectra is then justified as existing at working and reference electrode to the same extent, thus canceling each other out in the single electrode measurements.

Since reference concentrations have been shown to vary with respect to current, whether some or all diffusing species are responsible for the behavior should be considered. The difficulty in gas phase diffusion occurring equally at the reference as at the active electrode is in the large lowfrequency impedance at low current. Intuitively, the high impedance measured in the low frequency of the total cell is not likely to exist to an equal extent at the reference as at the active electrode due to gas concentration, because the change in gas concentration due to consumption is negligible near OCV. As for electrolytic mass transport, high mass transfer impedance at low current is also observed in lanthanum strontium manganese oxide (LSM) electrodes, which are known to be poor bulk ion conductors at low overpotentials. Impedance spectra obtained for thin, dense LSM films on yttria stabilized zirconia $[17,25]$ have abscissa in a similar frequency regime as depicted in the present study for the total cell as shown in Figure 4. These arcs have been attributed to oxide (or vacancy) diffusion through the film, as confirmed by the shift of the abscissa frequency at differing film thicknesses. Even though this Ceramatec cathode is not composed of LSM, the properties of other manganite-based materials appear to be similar in the equivalent circuit model.

Electrolytic mass transfer is further supported by comparing the fitted $B$ value between button and larger cells. For the specific cells in this study, the thicknesses of the mixed conducting layer of the electrodes were significantly different between the button cells and the large cells. The total thickness (including mixed conducting components) for the large cell anode and cathode is approximately 52$55 \mu \mathrm{m}$ and $77-80 \mu \mathrm{m}$, respectively, compared to $307-358 \mu \mathrm{m}$ and $347-398 \mu \mathrm{m}$ for the button cell. The effect that thinner electrodes impose on mass transfer is visually evident in the low-frequency semicircle being fully resolved for the large cell impedance compared to that of the button cells over the same frequency spectrum (Figures 3 and 4). The shift of the abscissa frequency between the two from approximately $10 \mathrm{mHz}$ to $200 \mathrm{mHz}$ is quantified by the $B$ parameter of the FDE, which changes due to the diffusion layer thickness. The ionic/interstitial oxygen (or vacancy) diffusion layer would be the sum of the thicknesses of the electrolyte and electrodes, assuming the majority of reactions occur on the outer edges of the electrodes. The ratio of the button cell $B$ to that of the large cell is approximately three at OCV, which is quite close to the ratio of the cathode thicknesses (2.76-3.04). Comparing higher current levels is likely not valid, because of temperature changes due to reaction heat generation in the larger cells.

3.3.2. Gas Conversion Impedance. Primdahl and Mogensen [26] observed a low-frequency impedance arc related to gas conversion, when the reference electrode was located in a different atmosphere from the working electrode. They proposed that the passage of AC current changes gas concentration at the active surface, most noticeably at low frequencies, resulting in a Nernstian potential loss. Such is not observed when the working and reference electrodes are at the same concentration, which could be the cause of the previously discussed reference $i-V$ behavior (Section 3.3.1) in Figure 8. Their study modeled the gas conversion impedance (GCI) with a parallel $R_{\mathrm{lf}}$ and $C_{\mathrm{lf}}$ in series with the electrode equivalent circuit (similar to the equivalent circuit described in Section 3.1.2, Figure 5(a)) and approximately replicated the fitted values with a constantly stirred tank reactor (CSTR) model yielding the following relationships:

$$
\begin{gathered}
R_{\mathrm{lf}}=\frac{R_{\mathrm{ig}} T}{(2 F)^{2} J}\left(\frac{1}{x_{w}}+\frac{1}{x_{H}}\right), \\
C_{\mathrm{lf}}=\frac{4 F^{2} P V}{\left(R_{\mathrm{ig}} T\right)^{2} A}\left(\frac{1}{x_{w}}+\frac{1}{x_{H}}\right)^{-1}
\end{gathered}
$$

wherein the resistance and capacitance are area specific. Applying Primdahl's model to the cells in question indicates that gas conversion may be partially responsible for the extra arc. 
TABLe 3: Values for a parallel RC fitted to the low-frequency impedance loops of three cells in a five-cell planar stack operating at $800^{\circ} \mathrm{C}$.

(a) The SOFCs were fed with $38.5 \sim 97 \% \mathrm{H}_{2}, 3 \% \mathrm{H}_{2} \mathrm{O}$, and balance $\mathrm{N}_{2}$, and operated at $1.69 \mathrm{~mA} \mathrm{~cm}^{-2}$

\begin{tabular}{|c|c|c|c|c|c|c|c|c|c|}
\hline \multirow{2}{*}{ Physical elements } & \multicolumn{3}{|c|}{$x_{\mathrm{H}}($ Cell 1) } & \multicolumn{3}{|c|}{$x_{\mathrm{H}}($ Cell 3) } & \multicolumn{3}{|c|}{$x_{\mathrm{H}}($ Cell 5) } \\
\hline & $38.5 \%$ & $64.6 \%$ & $97.0 \%$ & $38.5 \%$ & $64.6 \%$ & $97.0 \%$ & $38.5 \%$ & $64.6 \%$ & $97.0 \%$ \\
\hline$R_{\mathrm{lf}}\left(\Omega \mathrm{cm}^{2}\right)$ & 1.430 & 1.538 & 1.373 & 1.340 & 1.479 & 1.263 & 1.299 & 1.427 & 1.301 \\
\hline$C_{\mathrm{lf}}\left(\mathrm{F} \mathrm{cm}^{-2}\right)$ & 1.185 & 1.586 & 1.658 & 0.9477 & 1.342 & 1.465 & 0.9883 & 1.238 & 1.447 \\
\hline$Y_{0}\left(\mathrm{~S} \mathrm{~cm}^{-2} \mathrm{~s}^{1 / 2}\right)$ & 1.135 & 1.332 & 1.441 & 1.018 & 1.211 & 1.397 & 1.059 & 1.202 & 1.338 \\
\hline$B\left(s^{1 / 2}\right)$ & 2.025 & 2.487 & 2.402 & 1.727 & 2.210 & 2.155 & 1.743 & 2.098 & 2.149 \\
\hline
\end{tabular}

(b) Varying load currents when fed with $97.0 \% \mathrm{H}_{2}$ and balance $\mathrm{H}_{2} \mathrm{O}$

\begin{tabular}{|c|c|c|c|c|c|c|c|c|c|}
\hline \multirow{2}{*}{ Physical elements } & \multicolumn{3}{|c|}{$i\left(\mathrm{~mA} \mathrm{~cm}^{-2}\right.$, Cell 1$)$} & \multicolumn{3}{|c|}{$i\left(\mathrm{~mA} \mathrm{~cm}^{-2}\right.$, Cell 3) } & \multicolumn{3}{|c|}{$i\left(\mathrm{~mA} \mathrm{~cm}^{-2}\right.$, Cell 5) } \\
\hline & 1.639 & 52.46 & 147.5 & 1.639 & 52.46 & 147.5 & 1.639 & 52.46 & 147.5 \\
\hline$R_{\mathrm{lf}}\left(\Omega \mathrm{cm}^{2}\right)$ & 1.373 & 0.6570 & 0.5802 & 1.263 & 0.6283 & 0.4862 & 1.301 & 0.6082 & 0.4373 \\
\hline$C_{\mathrm{lf}}\left(\mathrm{F} \mathrm{cm}^{-2}\right)$ & 1.659 & 1.716 & 1.648 & 1.465 & 1.417 & 1.380 & 1.447 & 1.445 & 1.895 \\
\hline$Y_{0}\left(\mathrm{~S} \mathrm{~cm}^{-2} \mathrm{~s}^{1 / 2}\right)$ & 1.442 & 2.051 & 1.925 & 1.397 & 1.857 & 1.821 & 1.337 & 1.907 & 1.731 \\
\hline$B\left(\mathrm{~s}^{1 / 2}\right)$ & 2.402 & 1.668 & 1.554 & 2.156 & 1.467 & 1.376 & 2.148 & 1.457 & 1.259 \\
\hline
\end{tabular}

(c) Varying the anode feed rate $j$ when the SOFCs were operated at $52.46 \mathrm{~mA} \mathrm{~cm}^{-2}$ and composed of $97.0 \% \mathrm{H}_{2}$ and balance $\mathrm{H}_{2} \mathrm{O}$, where the total $j$ is assumed to be evenly distributed between the five cells in the stack.

\begin{tabular}{|c|c|c|c|c|c|c|}
\hline \multirow{2}{*}{ Physical elements } & \multicolumn{2}{|c|}{$j\left(\mu \mathrm{mol} \mathrm{s}{ }^{-1} \mathrm{~cm}^{-2}\right.$, Cell 1$)$} & \multicolumn{2}{|c|}{$j\left(\mu \mathrm{mol} \mathrm{s}^{-1} \mathrm{~cm}^{-2}\right.$, Cell 3$)$} & \multicolumn{2}{|c|}{$j\left(\mu \mathrm{mol} \mathrm{s}{ }^{-1} \mathrm{~cm}^{-2}\right.$, Cell 5 $)$} \\
\hline & 3.168 & 4.979 & 3.168 & 4.979 & 3.168 & 4.979 \\
\hline$R_{\mathrm{lf}}\left(\Omega \mathrm{cm}^{2}\right)$ & 0.8632 & 0.6570 & 0.8131 & 0.6283 & 0.7759 & 0.6082 \\
\hline$C_{\mathrm{lf}}\left(\mathrm{F} \mathrm{cm}^{-2}\right)$ & 1.910 & 1.716 & 1.648 & 1.417 & 1.734 & 1.446 \\
\hline$Y_{0}\left(\mathrm{~S} \mathrm{~cm}^{-2} \mathrm{~s}^{1 / 2}\right)$ & 1.956 & 2.051 & 1.900 & 1.857 & 1.952 & 1.907 \\
\hline$B\left(\mathrm{~s}^{1 / 2}\right)$ & 2.049 & 1.668 & 1.863 & 1.467 & 1.843 & 1.457 \\
\hline
\end{tabular}

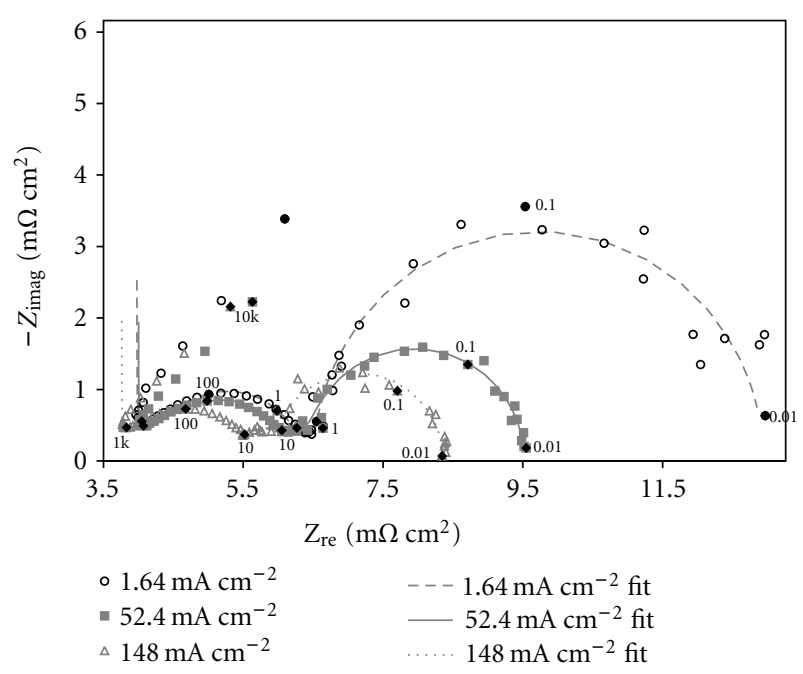

Figure 9: Nyquist plot of a planar fuel cell stack fed with $97 \% \mathrm{H}_{2}$ and balance $\mathrm{H}_{2} \mathrm{O}$ operating at $800^{\circ} \mathrm{C}$ and varying load current. The data have been fitted to a four-RC equivalent circuit.

While a $61 \mathrm{~cm}^{2}$ planar cell is expected to deviate from a single tank CSTR model due to the previously discussed distributed conditions, the general variation of impedance with each of the independent variables should be unchanged. Increases in cell current or hydrogen concentration predict that $R_{\mathrm{If}}$ should decrease and $C_{\mathrm{lf}}$ should increase, a tendency observed in the button cell fits in Tables 1(a) and 1(b). The same impedance effect should be observed for decreased temperature; however, $C_{\text {lf }}$ fits decrease by no less than $44 \%$ for a temperature decrement of $50^{\circ} \mathrm{C}$. Temperature was not explicitly controlled for the larger cells to test whether the same anomaly is present, but hydrogen concentration (Table 3(a)) and cell current (Table 3(b)) were varied with only the former behaving as in the button cell tests. Specifically, $C_{\text {lf }}$ is only slightly affected by increasing stack current from $1.639 \mathrm{~mA} \mathrm{~cm}^{-2}$ to $52.46 \mathrm{~mA} \mathrm{~cm}^{-2}$, although the model predictions and button cell data indicate a large increase should be observed. This effect cannot be justified by the expected increase in cell temperature induced by increasing current, because the GCI model indicates an increment of $\gg 100^{\circ} \mathrm{C}$ would be necessary for such a drastic shift to be observed. Notwithstanding the fact that the button cell fitted $C_{\text {If }}$ exhibit opposite behavior (Table 1(a)) with respect to the model predictions (5) at increased temperature. The opposite trend is not clear and further intensive work is necessary to examine the effect of temperature on the gas conversion impedance, especially on the value of $C_{\text {lf }}$ capacitance.

The best evidence that gas conversion is likely responsible for the low-frequency impedance loop is listed in Table 3(c), wherein an increase in the total anode gas flow decreases $R_{\mathrm{lf}}$ and decreases $C_{\text {lf }}$ The relationship between gas conversion impedance and anode feed rate $j$ has been demonstrated experimentally by Momma et al. [27], who applied it to determine the flow distribution through a 46-cell stack. Whether the low-frequency arc is due entirely to gas conversion is not conclusive enough to apply the same method to test the flow distribution in the Ceramatec stack. 
Neither gas conversion nor mass transfer is likely to exclusively cause the low-frequency impedance loop. The two can scarcely be distinguished from the appearance of the arc, because a parallel RC and FDE are similarly shaped on a Nyquist plot [28] as evident in the $\chi^{2}$ values of the fits. The difference is in the Warburg-like part of the FDE, which appears as a $45^{\circ}$ line on a Nyquist plot to the higher frequency side of the FDE abscissa [20]. Anode adsorption occurs in the same frequency regime as the Warburg part of the FDE, which obscures the shape of the low-frequency loop. Exacerbating the choice of elements is the functionality of (2) and (4), which indicates that $R_{\mathrm{If}}$ and $Y_{0}$ often vary inversely; however, such a relationship is not always observed in the values listed in Table 3 . The correlation between fitted values and changes in hydrogen concentration or temperature is more congruent with mass transfer, while gas conversion better explains that of gas flow rate. The effects of gas conversion and mass transfer are most likely present concurrently being superimposed as an arc in the low-frequency region of a Nyquist plot.

The utility of applying equivalent circuit models for mechanistically discriminating problems with individual cell performance is evident in analyzing the different large cells. In the stack under investigation, Cell 3 is in the middle of the stack flanked by Cells 1 and 5 on the outsides. The two outside cells are not identical, with Cell 5 having a thermally insulating layer adjacent to the outer wall that is unique to it. Because the temperature of Cell 1 is lower than the other cells in the stack, it lacks the thermal energy necessary to drive the reaction as fast, thus limiting performance in a stack of cells connected in series. One need not know the geometry of the system to deduce that Cell 1 is at a lower temperature than the others; such can be implied from the model fits. While the increased $R_{\mathrm{ct}}$ for the cell in question may indicate a decreased temperature, the trend may also be induced by inconsistent electrode microstructure, catalyst loading, and/or reactant concentration. Coupling the $R_{\mathrm{ct}}$ behavior with the increase in $R_{\Omega}$ and $B$ for Cell 1 relative to the other cells proves the root of the problem, because decreased electrolyte conduction and diffusivity are also indicative of lower temperatures. The analyses of the fitted large cell data show how impedance spectroscopy can be used to mechanistically discriminate the factors that limit stack performance.

3.4. Fuel Cell Stack. Data for the entire fuel cell stack were also obtained under the same test conditions as the single cell tests previously described in Sections 3.2 and 3.3. Figure 9 depicts some of the obtained curves, each of which is similar in shape to the individual cells; hence, the same equivalent circuit that was fitted to the large cell data has been similarly applied to the stack data. The key to the success of applying an individual cell model to a stack of cells is the distribution of RC circuits of each physical relaxation process from cell to cell. Although not precisely equal between the five cells, the frequency ranges at which each physical process dominates cell impedance are similar enough for the arcs to superimpose. Had the degree of distribution been greater, the semicircles of the Nyquist plot would have appeared to be depressed (CPE-like); instead, the individual cell model is well fitted to the stack impedance data, as exhibited in this figure.

While the individual cell tests were designed to determine which processes limit cell output and to what degree, the stack test is primarily intended to obtain a simple, purely electronic model to replicate the dynamic response of the stack. In order to represent the stack the purely physical electronic elements, the FDE of the equivalent circuit (Figure 6) has been replaced with a parallel RC, which has already been shown to fit single cell data equally well. Obtaining fits for the circuit elements over the expected range of operation allows for the stack to be dynamically modeled over said range. The utility in eliminating all distributed elements from the model is to facilitate circuit simulation [12], which can be used to design process controls and to assess the optimum configuration of operating conditions, power conditioning systems, and combination of multiple stacks.

\section{Conclusions}

In the work presented, impedance spectroscopy was successfully applied to solid oxide fuel cells and stacks at different operating conditions. Improved equivalent circuit models were proposed and applied for fitting of button cells and larger cells in the stack. A relaxation process unique to the total cell data was measured at low frequency and has been suggested to be due to the combined effects of mass transfer and gas conversion. The total-cell circuit model is further simplified and adjusted to simulate the SOFC larger cells in a five-cell stack. The cause for an underperforming cell in the stack was attributed to temperature, based on a comparison with the data from two other cells in the same stack. The entire fuel cell stack was fitted to a model developed from the single cells, only with distributed elements replaced with physical electrical elements. The stack circuit diagram and associated physical elements are essential to simulate its dynamic behavior to facilitate system design. The work contained herein is useful for assessing in situ stack dynamics, stack aging, state of health, system controls, component fabrication, and quality control.

\section{Nomenclature}

A: Area $\left(\mathrm{cm}^{2}\right)$

$B$ : Constant related to the time for a reactant to diffuse through a thin film $\left(\mathrm{s}^{1 / 2}\right)$

C: Capacitance $\left(\mathrm{mF} \mathrm{cm}^{-2}\right)$

c: Concentration $\left(\mathrm{mol} \mathrm{m}^{-3}\right)$

$D$ : Diffusion coefficient $\left(\mathrm{cm}^{2} \mathrm{~s}^{-1}\right)$

F: Faraday's constant ( $96487 \mathrm{As} \mathrm{mol}^{-1}$ )

$j$ : Flow rate per area of electrode $\left(\mathrm{mol} \mathrm{s}^{-1} \mathrm{~cm}^{-2}\right)$

$J$ : Imaginary constant $(-1)^{0.5}$

$i$ : Current density $\left(\mathrm{mA} \mathrm{cm}^{-2}\right)$

$L$ : Inductance $(\mathrm{H})$

$n$ : Stoichiometric number of electrons involved in a chemical reaction

$P$ : Pressure $(\mathrm{Pa})$

$R$ : Resistance $(\mathrm{m} \Omega)$ 
$R_{\mathrm{ig}}$ : Ideal gas constant $\left(8.314 \mathrm{~J} \mathrm{~mol}^{-1} \mathrm{~K}^{-1}\right)$

$V$ : Volume of CSTR $\left(\mathrm{cm}^{3}\right)$

T: Temperature (K)

$x$ : Mole fraction at inlet

$Y_{0}$ : Magnitude of the admittance $\left(Y_{0}=\right.$ $\left.1 /\left.Z\right|_{\omega=1 \mathrm{rad} / \mathrm{s}(f \approx 0.16 \mathrm{~Hz})}\left(\mathrm{S} \mathrm{cm}^{-2} \mathrm{~s}^{1 / 2}\right)\right)$

$Z: \quad$ Impedance $\left(\mathrm{m} \Omega \mathrm{cm}^{2}\right)$

Greek Letter

$\delta$ : Diffusion layer thickness $(\mathrm{cm})$

Subscripts

$\begin{array}{ll}\text { ct: } & \text { Charge-transfer } \\ d: & \text { Double-layer } \\ H: & \text { Hydrogen } \\ i: & \text { Species } \\ \text { imag: } & \text { Imaginary } \\ L: & \text { Related to adsorption } \\ \text { lf: } & \text { Low frequency } \\ \text { re: } & \text { Real } \\ W: & \text { Water } \\ \theta: & \text { Related to adsorption } \\ \Omega: & \text { Ohmic }\end{array}$

Superscripts

a: Anode

$c$ : Cathode

\section{Acknowledgments}

The authors would like to thank Dennis Larsen, Piotr Czernichowski, Lyman Frost, Anthony Nickens, and everyone else at Ceramatec Inc. who helped make this project possible. they would also like to thank Dr. Jeffrey W. Fergus for his help with understanding solid-state electrolytes. Additionally, the authors would like to recognize Ronald Putt for his knowledge of electrochemistry and for proofreading this paper.

\section{References}

[1] Q. A. Huang, B. Wang, W. Qu, and R. Hui, "Impedance diagnosis of metal-supported SOFCs with SDC as electrolyte," Journal of Power Sources, vol. 191, no. 2, pp. 297-303, 2009.

[2] S. C. Singhal and K. Kendal, High Temperature Solid Oxide Fuel Cells Fundamentals, Design and Applications, Elesvier, Oxford, UK, 2003.

[3] Q. A. Huang, R. Hui, B. Wang, and J. Zhang, "A review of AC impedance modeling and validation in SOFC diagnosis," Electrochimica Acta, vol. 52, no. 28, pp. 8144-8164, 2007.

[4] H. L. Hellman and R. van den Hoed, "Characterising fuel cell technology: challenges of the commercialisation process," International Journal of Hydrogen Energy, vol. 32, no. 3, pp. 305-315, 2007.

[5] R. U. Payne, Y. Zhu, W. H. Zhu, B. J. Tatarchuk, S. Elangovan, and M. Timper, "Determining kinetic and mass transfer limiting behavior of a solid oxide fuel cell via AC impedance," in Proceedings of the 2008 AIChE Annual Meeting, pp. 119/1119/4, Philadelphia, Pa, USA, 2008.
[6] D. Larrain, J. Van herle, and D. Favrat, "Simulation of SOFC stack and repeat elements including interconnect degradation and anode reoxidation risk," Journal of Power Sources, vol. 161, no. 1, pp. 392-403, 2006.

[7] R. U. Payne, W. H. Zhu, and B. J. Tatarchuk, "Mechanistic discrimination of circuit elements in solid oxide fuel cell equivalent circuit models," in Proceedings of the 43rd Power Sources Conference, pp. 327-330, Philadelphia, Pa, USA, July 2008.

[8] J. I. Gazzarri and O. Kesler, "Electrochemical AC impedance model of a solid oxide fuel cell and its application to diagnosis of multiple degradation modes," Journal of Power Sources, vol. 167, no. 1, pp. 100-110, 2007.

[9] W. H. Zhu, R. U. Payne, and B. J. Tatarchuk, "PEM stack test and analysis in a power system at operational load via ac impedance," Journal of Power Sources, vol. 168, no. 1, pp. 211217, 2007.

[10] D. R. Cahela, W. C. Dillard, R. M. Nelms, R. Putt, and B. J. Tatarchuk, "Zinc-air battery/double layer capacitor hybrid for portable communications pulse power supply," in Proceedings of the 38rd Power Sources Conference, pp. 61-64, Cherry Hill, NJ, USA, June 1998.

[11] T. E. Springer, "Applications of AC impedance to fuel cell modeling," Electrochemical Society Proceedings, vol. 99-14, pp. 208-221, 1999.

[12] W. H. Zhu, R. U. Payne, R. M. Nelms, and B. J. Tatarchuk, "Equivalent circuit elements for PSpice simulation of PEM stacks at pulse load," Journal of Power Sources, vol. 178, no. 1, pp. 197-206, 2008.

[13] K. An, K. L. Reifsnider, and C. Y. Gao, "Durability of composite cathodes for solid oxide fuel cells," Journal of Power Sources, vol. 158, no. 1, pp. 254-262, 2006.

[14] M. J. L. Oestergard and M. Mogensen, "Ac impedance study of the oxygen reduction mechanism on lanthanum strontium manganese oxide $\mathrm{La}_{1-\mathrm{x}} \mathrm{Sr}_{\mathrm{x}} \mathrm{MnO}_{3}$ ) in solid oxide fuel cells," Electrochimica Acta, vol. 38, no. 14, pp. 2015-2020, 1993.

[15] T. Kato, K. Nozaki, A. Negishi et al., "Impedance analysis of a disk-type SOFC using doped lanthanum gallate under power generation," Journal of Power Sources, vol. 133, no. 2, pp. 169$174,2004$.

[16] M. Liu, Z. Lu, B. Wei et al., "Anode-supported micro-SOFC stacks operated under single-chamber conditions," Journal of the Electrochemical Society, vol. 154, no. 6, pp. B588-B592, 2007.

[17] M. Lang, C. Auer, A. Eismann, P. Szabo, and N. Wagner, "Investigation of solid oxide fuel cell short stacks for mobile applications by electrochemical impedance spectroscopy," Electrochimica Acta, vol. 53, no. 25, pp. 7509-7513, 2008.

[18] B. A. Boukamp, "Interpretation of an "inductive loop" in the impedance of an oxygen ion conducting electrolyte/metal electrode system," Solid State Ionics, vol. 143, no. 1, pp. 47-55, 2001.

[19] J. Winkler, P. V. Hendriksen, N. Bonanos, and M. Mogensen, "Geometric requirements of solid electrolyte cells with a reference electrode," Journal of the Electrochemical Society, vol. 145, no. 4, pp. 1184-1192, 1998.

[20] B. Rogers, "Research solutions and references," 2008, http:// www.consultrsr.com/resources/eis/diff-o.htm.

[21] C. N. Cao, "On the impedance plane displays for irreversible electrode reactions based on the stability conditions of the steady-state-II. Two state variables besides electrode potential," Electrochimica Acta, vol. 35, no. 5, pp. 837-844, 1990.

[22] A. Barbucci, M. Viviani, P. Carpanese, D. Vladikova, and Z. Stoynov, "Impedance analysis of oxygen reduction in SOFC 
composite electrodes," Electrochimica Acta, vol. 51, no. 8-9, pp. 1641-1650, 2006.

[23] R. P. O'Hayre, S.-W. Cha, and W. Colella, Fuel Cell Fundamentals, John Wiley \& Sons, Hoboken, NJ, USA, 2006.

[24] C. J. Geankoplis, Transport Processes and Unit Operations, Prentice Hall PTR, Upper Saddle River, NJ, USA, 3rd edition, 1993.

[25] T. Ioroi, T. Hara, Y. Uchimoto, Z. Ogumi, and Z. I. Takehara, "Preparation of perovskite-type $\mathrm{La}_{1-\mathrm{x}} \mathrm{Sr}_{\mathrm{x}} \mathrm{MnO}_{3}$ films by vapor-phase processes and their electrochemical properties: II. Effects of doping strontium to $\mathrm{LaMnO}_{3}$ on the electrode properties," Journal of the Electrochemical Society, vol. 145, no. 6, pp. 1999-2004, 1998.

[26] S. Primdahl and M. Mogensen, "Gas conversion impedance: a test geometry effect in characterization of solid oxide fuel cell anodes," Journal of the Electrochemical Society, vol. 145, no. 7, pp. 2431-2438, 1998.

[27] A. Momma, Y. Kaga, K. Takano et al., "AC impedance behavior of a practical-size single-cell SOFC under DC current," Solid State Ionics, vol. 174, no. 1-4, pp. 87-95, 2004.

[28] A. Lasia, "Electrochemical impedance spectroscopy and its applications," in Modern Aspects of Electrochemistry, B. E. Conway, J. O. M. Bockris, and R. E. White, Eds., no. 32, pp. 143-242, Kluwer Academic, New York, NY, USA, 1999. 


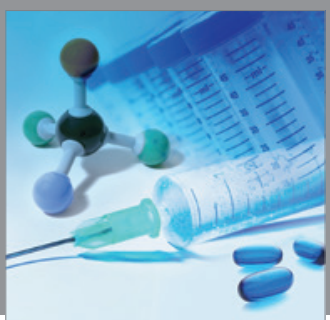

International Journal of

Medicinal Chemistry

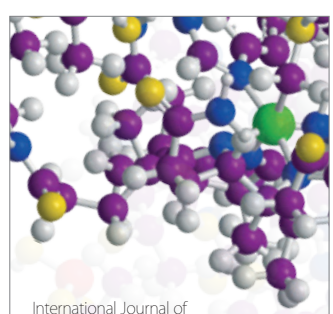

Carbohydrate Chemistry

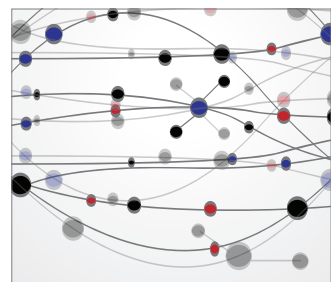

The Scientific World Journal
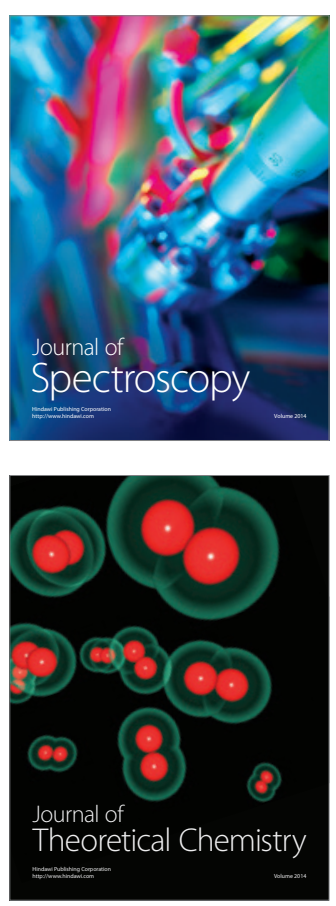
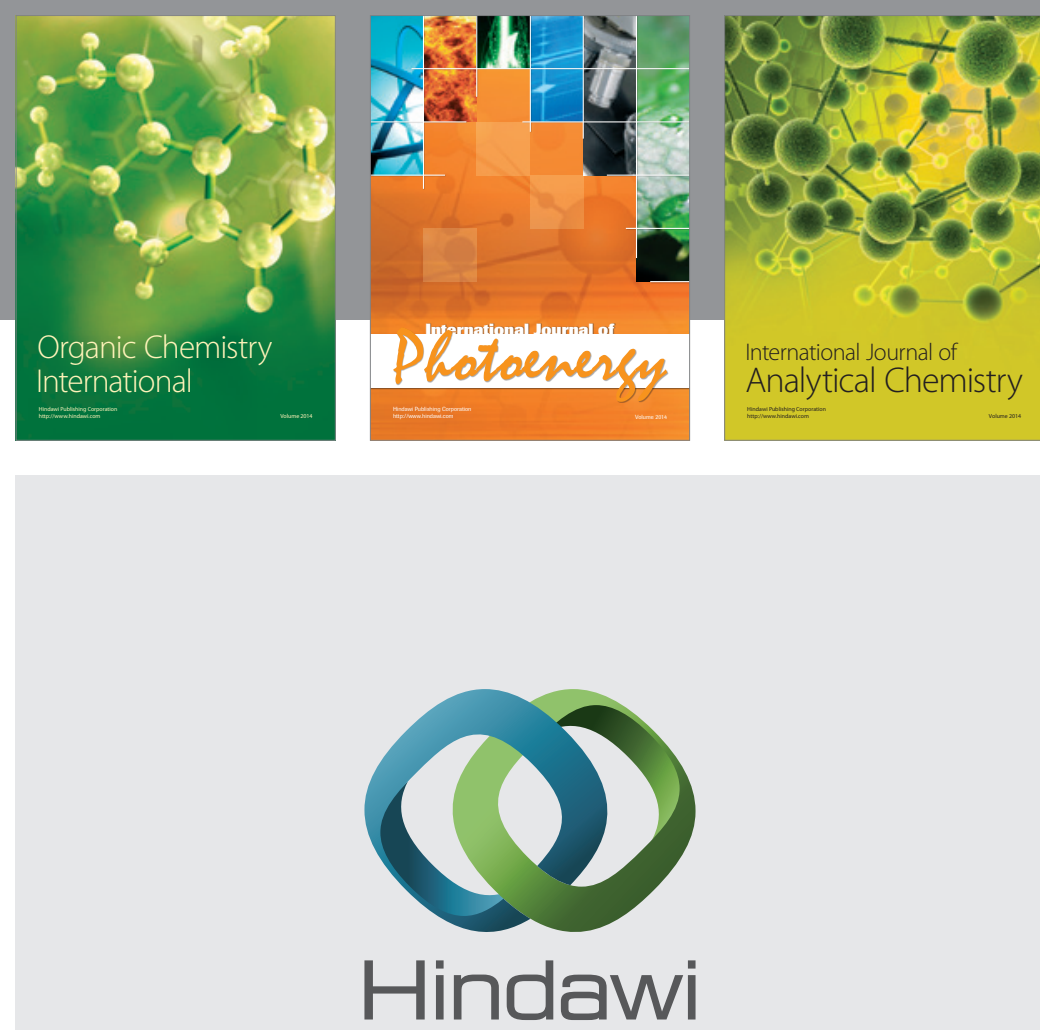

Submit your manuscripts at

http://www.hindawi.com
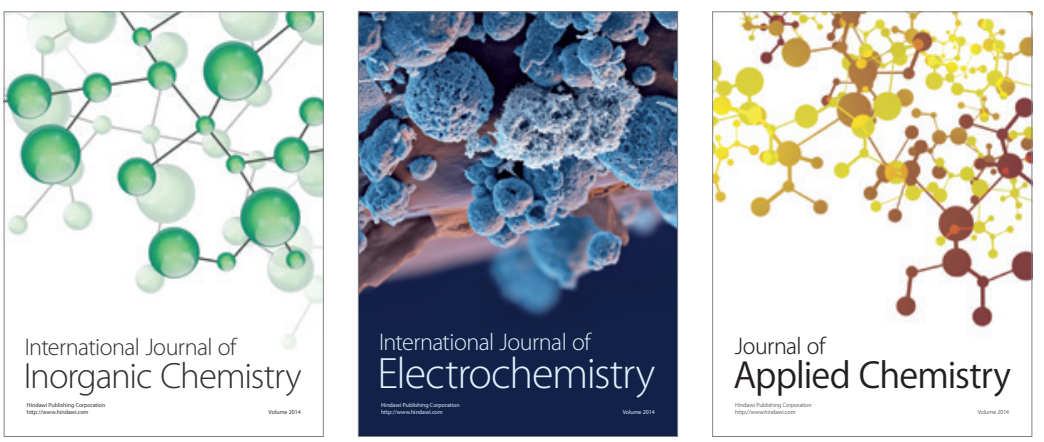

Journal of

Applied Chemistry
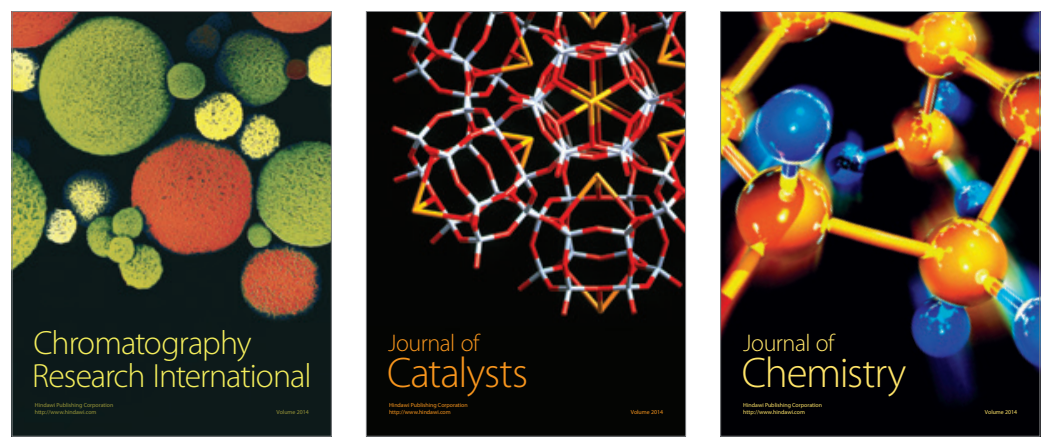
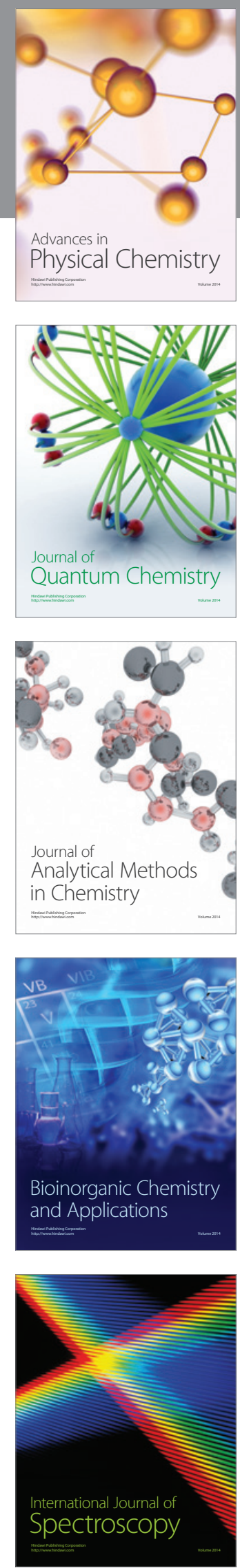